\title{
Sochi 99
}

\author{
By Ron Holloway \\ Spring 2000 Issue of KINEMA
}

\section{THE 10th SOCHI INTERNATIONAL FILM FESTIVAL}

ASK ANY devotee of the Sochi International Film Festival, and you will hear that this innovative and visionary festival on the Black Sea, founded by Mark Rudinstein under the nickname "Kinotavr" with actor Oleg Yankovsky as festival president, far outstrips all other Russian film events when it comes to programming the best national feature films and debut productions made in the course of a year. Lately, under programming directors Sergei Lavrentiev and Andrei Plakhov, the festival has shifted into high gear until, for its 10th anniversary celebration (3-14 June 1999), it expanded its horizon to include an international competition devoted to "Young Directors" and secure the support of the nation-wide Russian TV Channel to cover the event. Indeed, this "Black Sea Riviera" with its subtropical climate, palm trees, first-class hotels, beach restaurants, and bevy of prominent guests needs only an international airport to number it among Europe's key festival attractions.

Three sections: International Competition, Russian Features, and Russian First Films judged by four juries (including FIPRESCI) made it almost impossible to see everything of note and promise, unless perhaps the visitor has had the good fortune to travel to Berlin, Cannes, Venice and Rotterdam, where most of the selections for the international program have been made. For instance, Sochi's Grand Prix, Patrice Toye's Rosie (Belgium), had already been seen at the Berlinale in the Panorama section. The film features a riveting performance by Aranka Coppens as a 14-year-old daydreamer whose imaginary companion offers the only relief she can find from daily woes.

Dorota Kedzierzawska's Nic (Nothing, Poland) was doubly honoured with a Special Jury Prize and a FIPRESCI Prize. Filmed in an expressionist style and remarkable for its striking camera technique, it's about a wisp of a girl, cut from the same mould as Lillian Gish in a D.W. Griffith film, who suffers a fate worse than death. An impoverished mother of three children, she kills her newborn for fear of losing her husband, a Mater Dolorosa in a Catholic Poland, where the church offers little respite from her misery.

The national competition for the best Russian feature heated up fast when it was announced that one of the favourites, Vasily Pichul's A Sky in Diamonds (Russia-France), was being withdrawn without any reasons given but on the assumption that an international festival had put in a bid for the film. Then, when Alexander Rogozhkin's Blockpost (Checkpoint) was voted the Grand Prix, Alexander Sokurov left word that he was withdrawing his Moloch (Russia-Germany) from consideration for the runner-up Special Jury Prize on the grounds that the jury's decision was a "political" one. As for Checkpoint, a remarkably honest and critical portrait of the ongoing war in the Caucasus (but a short distance away from Sochi), it was also awarded a FIPRESCI prize. As experienced by young recruits in the Russian Army, all of whom are ill prepared for the rigours of patrolling a frontier checkpoint, the enemy for the most part remains invisible and hidden in the mountainous terrain.

Other festival highlights included a 13-film retrospective tribute to Krzysztof Zanussi (jury president) and a pair of warmly received special-event screenings Kwangmo Lee's Spring in My Hometown (South Korea), a postwar chronicle, was hailed as a minor masterpiece when it premiered in the Directors Fortnight at the 1998 Cannes festival. And Lukas Moodysson's Fucking Amål (Show Me Love, Sweden-Denmark) scores as a delightful comedy about teenagers bored to tears in a small provincial Swedish town where nothing ever happens.

Finally, Galina Dolmatovskaya's documentary, Ivan Mosjoukine, or the Carnival Child (Russia), chronicles the brilliant career of one of Russia's great silent film stars, who went on to achieve fame in French silent cinema as well, with an assortment of photos, archival footage, and location shots. Ivan Mosjoukine (18891939) sometimes spelled Mosjukine or Moskine or Mozhukhin was a stage and screen idol in the Czar era. Later, he gained even greater fame in French cinema as an exotic leading man, and on occasion he worked 
in Germany and Hollywood (in Edward Slovman's Surrender, 1927). Then came sound and his career ended abruptly when it was discovered that his voice did not fit the roles he was playing. Mozhukhin died poor and forgotten in a mental clinic.

\section{Author Information}

Ron HOLLOWAY (1933-2009) was an American critic, film historian, filmmaker and correspondent who adopted Europe as his home in the early fifties and spent much of his life in Berlin. He was an expert on the study of German cinema and against all odds produced, with his wife Dorothea, the journal German Film, keeping us up-to-date with the work of directors, producers and writers and the showing of German films around the world.

In 2007, Ron Holloway and his wife were awarded the Berlinale Camera Award. Ron also received the Bundesverdienstkreuz (German Cross of Merit), Polish Rings, Cannes Gold Medaille, the American Cinema Foundation Award, the Diploma for Support of Russian Cinema and an honorary award from the German Film Critics' Association.

Ron was also a valued contributor to Kinema for the past fifteen years. 